\title{
WYSOKOŚĆ WYNIKU FINANSOWEGO PRZEDSIĘBIORSTW W ŚWIETLE POLSKIEGO PRAWA BILANSOWEGO
}

\section{WSTEP}

Istniejący w Polsce dualizm zobligowań prawnych oparty jest na rozdzielnym przyporządkowaniu podmiotów gospodarczych. W wypadku giełdowych spółek akcyjnych prymat jurysdykcyjny posiadają uregulowania Międzynarodowych Standardów Rachunkowości nad - kolejno - polską ustawą o rachunkowości i Krajowymi Standardami Rachunkowości. Pozostałe przedsiębiorstwa, z wyłączeniem banków, spółdzielni i jednostek sfery budżetowej, w zakresie prowadzenia rachunkowości w pierwszym rzędzie uwzględniaja ustawę o rachunkowości, a następnie - Międzynarodowe i Krajowe Standardy Rachunkowości.

W niniejszym artykule poddaje się analizie wpływ metod rachunkowości uwzględnionych $\mathrm{w}$ ustawie o rachunkowości na definiowanie wyniku finansowego. Istotne znaczenie ma tu zalegalizowanie metod dopuszczających różny posób rozliczeń identycznych zjawisk bądź procesów gospodarczych. Wybór którejś spośród tych metod pozostawiono podmiotom gospodarczym. Rezultatem tego jest sytuacja, w której to przedsiębiorstwa, bez względu na zakres i faktyczną skuteczność działań gospodarczych, mają wpływ na wysokość wykazywanych w sprawozdawczości wyników finansowych. Przedsiębiorstwa moja dużą swoboda w zakresie wyboru momentu i wysokości aktywowania kosztów bilansowych czy nawet uwzględniania niektórych przychodów. Poprzez wpływ tych działań na swoją sprawozdawczość finansową moga wpływać na zachowania interesariuszy. Istnieje więc kluczowa zależność między charakterem polskiego prawa bilansowego a zarządzaniem relacjami z interesariuszami przedsiębiorstwa.

Rozliczenia stosowane w rachunkowości stanowią formę umowy społecznej popartej przepisami prawa o normie ustawy. Umowa ta zakłada, że efekt właściwego zastosowania tych norm pozwoli na:

- ustalenie osiagnięć danego podmiotu gospodarczego bieżących i w rozkładzie czasowym, co umożliwić ma weryfikowanie zmian w sposobach zarządzania i ich wpływu na efektywność podmiotu gospodarczego,

- pozyskanie miarodajnych informacji służących podjęciu racjonalnych decyzji odnośnie do alokacji posiadanych środków finansowych przez potencjalnych inwestorów, 
- przeprowadzenie ogólnogospodarczego planowania opartego na informacjach statystycznych pochodzących $\mathrm{z}$ różnych branż, w tym informacji pozwalających na dokonanie korekt konsolidacyjnych w ramach poszczególnych sektorów gospodarki.

Powyższe kategorie wkomponowane sa w ramy obrotu gospodarczego i roli rachunkowości jako struktury chroniącej ten obrót. Rachunkowość w postaci sprawozdań finansowych winna bazować na obszernej wiedzy dotyczącej ekonomicznych aspektów funkcjonowania przedsiębiorstwa, stosując mechanizmy wiarygodnego opisu procesów i zjawisk gospodarczych w danym przedsiębiorstwie. Tymczasem dopuszczenie wariantowych rozwiązań $\mathrm{w}$ prawie bilansowym spowodowało podważenie możliwości skutecznej realizacji powyższych celów.

W artykule używa się kilku wprowadzanych lub modyfikowanych przez autora pojęć. Są nimi:

- „,inżynieria rachunkowości” ${ }^{1}$ definiowana jako zgodny z obowiązującym prawem bilansowym zespół działań księgowych, których najistotniejszym celem jest umożliwienie realizacji postawionych przed zarządami celów przez właścicieli kapitału. To typ zarządzania zasobami finansowymi przedsiębiorstwa, w którym podstawowym celem jest wykazanie zgodności efektu działań gospodarczych z wyartykułowanymi zamierzeniami. Inżynieria rachunkowości wyznacza więc poziom skorelowania działań księgowych z zarządzaniem przedsiębiorstwem (,zarządczego aspektu rachunkowości”);

- „rachunkowość wariantowa” ${ }^{2}$ będąca zestawem wariantowych (alternatywnych i opcyjnych) rozwiązań w polskim prawie bilansowym. Rozwiązania te charakteryzują się różnym ,szczątkowym” księgowym wynikiem identycznych działań gospodarczych;

- kategoria pojęciowa „impression management” będąca takim księgowym opisem działań przedsiębiorstwa (sprawozdawczości finansowej), którego celem nie jest obiektywna prezentacja danych finansowych, lecz wpłynięcie na odbiorcę sprawozdań. Zarządzanie prezentacją danych finansowych służyć ma skłonieniu interesariuszy przedsiębiorstwa do podjęcia przez nich korzystnych dla tegoż przedsiębiorstwa działań lub zaniechania działań potencjalnie przynoszących przedsiębiorstwu szkodę.

${ }^{1}$ Pierwotna definicja w: S. T. Surdykowska, Kreatywna inżynieria księgowa. W poszukiwaniu kozta ofiarnego, „Nasz Rynek Kapitałowy” 2003, nr 1(145). W publikacjach L. Michalczyka uznaje się „kreatywność inżynierii” za pojęcie wewnętrznie sprzeczne (również pojęcia: „inżynieria księgowa” oraz „kreatywna rachunkowość” są, w świetle logiki semantycznej, wewnętrznie sprzeczne) - por. szerzej głównie: L. Michalczyk, Rola inżynierii rachunkowości w ksztattowaniu wyników finansowych przedsiębiorstw (maszynopis, praca doktorska), WZiKS UJ, Kraków 2011.

${ }^{2}$ Pierwotna definicja w: B. Micherda, Analityczna funkcja rachunkowości, Wyd. AE Kraków, Kraków 2001. W ujęciu stosowanym w niniejszym artykule uznaje się zgodność wariantowości z łacińskim leksykalnym podejściem do tego pojęcia. W pracy B. Micherdy zastosowano synonimiczność ujęć: „wariant”, „opcja” i ,,alternatywa” (podobnie jak w języku angielskim). Zgodnie z zasadami logiki semantycznej oraz znaczeniem poszczególnych sformułowań: (1) każdy wybór jest wariantem, (2) jeśli następuje wybór jednej z dwóch możliwości - jest to alternatywa, (3) jeśli możliwości jest więcej - jest to opcja. 
Artykuł kończy charakterystyka etyki kapitalistycznej, będąca elementem uzasadnienia podejmowania działań $\mathrm{z}$ zakresu inżynierii rachunkowości głównie przez służby księgowe przedsiębiorstw ${ }^{3}$.

W niniejszym opracowaniu odróżnia się pojęcie ,prawo gospodarcze” od „,prawa bilansowego”. Pierwsze jest określeniem szerszym, skupiającym również takie elementy, jak chociażby ,,prawo handlowe” (kodeks handlowy), prawo pracy itp. Z kolei ,,prawo bilansowe” jest oparte przede wszystkim na polskiej ustawie o rachunkowości ${ }^{4}$.

Prezentowane rozważania stanowią element cyklu publikacji związanego $\mathrm{z}$ autorskim interdyscyplinarnym zagadnieniem inżynierii rachunkowości i jej roli w zarządzaniu przedsiębiorstwem.

\section{CHARAKTERYSTYKA WARIANTOWOŚCI POLSKIEGO PRAWA BILANSOWEGO}

Rachunkowość przedsiębiorstw opiera się na umieszczonych w różnych segmentach prawa bilansowego zasadach rachunkowości ${ }^{5}$. Im poziom języka przepisów prawnych jest bardziej nieprecyzyjny, tym większa jest możliwość subiektywizacji znaczeniowej działan opisywanych przez ten język. Zdaniem S. T. Surdykowskiej, język ten wynika z różnicującego się otoczenia gospodarczego przedsiębiorstw ${ }^{6}$. Idąc droga takiego rozumowania, należałoby wyciagnąć wniosek, że im bardziej nieprecyzyjny język, tym więcej możliwych aspektów relacji przedsiębiorstwa $\mathrm{z}$ jego otoczeniem społeczno-gospodarczym (przynajmniej tych, które maja wpływ na wartość rynkowa) jest w stanie ująć. Problem jednak tkwi w tym, że to rozumowanie, powszechnie akceptowane $\mathrm{w}$ nauce, jakkolwiek w teoretycznych pracach naukowych (opartych na systemach założeń i wzorców) słuszne, przeniknęło z rozważań teoretycznych do unormowań prawnych. Tymczasem prawo stawiać winno jasne i klarowne wytyczne działań opartych na przymusie, a nie dobrowolności ich podjęcia lub zaniechania.

${ }^{3}$ Szerzej ten aspekt analizuje się od strony ,,podejścia praktyki księgowej” w: L. Michalczyk, Etos polskiego ksiegowego - artykut dyskusyjny, „Zeszyty Teoretyczne Rachunkowości” 2011, nr 61 (117), s. 107-129. Istniejące kodeksy etyki zawodowej są przez autora uznawane za elementy teorii życzeniowej-por. analiza w: L. Michalczyk, Accountability i responsibility jako wyznaczniki odpowiedzialności biznesu w inżynierii rachunkowości, ,Pieniądze i Więź” (w druku). Opiera się ona na założeniu, że ludzie działają w interesie ogólnospołecznym i brak jest dążenia do wykorzystania dla własnych celów wszelkiego braku precyzji w istniejących przepisach prawnych. Nie oznacza to braku zasadności w ich stosowaniu, ale teoria ta jest niezgodna z kapitalistyczną relacja pracodawca-pracobiorca oparta na zasadzie: ,„płacę więc żądam”, która w sytuacji rynkowej czy to na poziomie księgowego (rynek pracy-bezrobocie), czy zewnętrznego audytora (rynek usług-dochodowość) ma decydujące znaczenie.

${ }^{4}$ Ustawa z 29 września 1994 r. o rachunkowości Dz. U. 2002, Nr 76, poz. 694 z późn. zm. (dalej u.o.r.).

5 J. Krynicki, J. Trzemżalski, Praktyczne aspekty polityki rachunkowości, „Przegląd Podatkowy” 2004, nr 3, s. 55.

${ }^{6}$ Por. stwierdzenie S. T. Surdykowskiej o braku możliwości jednoznacznego zdefiniowania przedmiotu i sposobu pomiaru w rachunkowości-eadem, Wycena w środowisku nowej ekonomii-wartość księgowa kontra wartość rynkowa, w: Problemy wyceny w rachunkowości, ZN AE we Wrocławiu, nr 911, Wrocław 2002, s. 259. 
Z punktu widzenia propedeutyki prawa fakultatywność działań wydaje się podejściem wyjątkowo kontrowersyjnym, gdyż powoduje fakultatywność ich prawnej oceny. Kategoria dobrowolności jest zbędną z punktu widzenia rozwiązań przewidzianych $\mathrm{w}$ prawie, w tym także prawie bilansowym. Niezastosowanie się do przepisów prawnych winno skutkować sankcją, której świadomość winien posiadać każdy podmiot niestosujący się do działań wskazanych w normie prawnej. Jeśli język prawa jest nieprecyzyjny, nie istnieje też precyzyjna wykładnia postaw, zachowań lub działań zgodnych czy też niezgodnych z prawem. Wartość takiej normy prawnej jest więc wyjątkowo dyskusyjna.

Ujęcia teoretyczne zawarte w u.o.r. w postaci akceptacji i rozwinięcia zasady jasnego i rzetelnego obrazu (true and fair view) w praktyce winny uniemożliwiać wybór oparty na zasadzie istotności. Zasady te są wzajemnie sprzeczne, a przez to umożliwiaja ,,uznaniowe”, a zarazem opcyjnie podejście do określania wyniku bilansowego przedsiębiorstw. Polska u.o.r., już w zakresie swego memorandum zawierającego wykaz zasad rachunkowości, którymi winno kierować się przedsiębiorstwo, wyodrębnia obowiązek stosowania zasad rzetelności (art. 4 ust. 1) i istotności (art. 8 ust. 1). Zasady te w rachunkowości sa sobie przeciwstawne. „Rzetelność” oznacza ujęcie całości zagadnień, „,istotność" - wybór spośród zagadnień. W istniejąca przeciwstawność wkomponowuja się również zasady ostrożności (art. 7 ust. 1 i 2 ) i współmierności (art. 6 ust. 2). Wynikaja one z braku refleksji prawodawcy „przenoszącego” konstrukcje teoretyczne rachunkowości wariantowej do przepisów prawnych. Teoria rachunkowości zakłada, że jej ujęcia będą dodatkowo weryfikowane przez „zachowującego zdrowy rozsądek” hipotetycznego księgowego. Przyjęcie przez legislatorów takiego założenia oznacza, że dają oni praktykom zalegalizowana broń w postaci dowolności działań.

Podobnie rzecz ma się z relacją między zasadą współmierności kosztów i przychodów a zasadą ostrożności. Pierwsza kładzie nacisk na potrzebę wykazywania krótkoterminowych zysków, druga prowadzi do zakładania rezerw zmierzających do ,wygładzania zysków w długim okresie"7 oraz zapewnienia stabilności wyników w długim przeciąu czasu ${ }^{8}$. Ostrożna wycena pozbawia inwestora bieżących korzyści $\mathrm{z}$ inwestycji, ponieważ tworzone rezerwy zmniejszają wielkość zysku dostępnego do podziału w postaci dywidendy. Z drugiej strony ostrożna wycena zmniejsza ryzyko inwestowania. Współmierność kosztów i przychodów powoduje potencjalne większe korzyści bieżące dla inwestora przy zwiększonym ryzyku inwestycji.

Ustawa o rachunkowości przyjmuje dwa sposoby zachowania się w stosunku do metod będących przedmiotem wyboru przez przedsiębiorstwo:

- dopuszcza wybór spośród katalogu ściśle określonych rozwiązań i zasad,

- pozostawia jednostce swobodę określoną ramami obowiązujących nadrzędnych zasad rachunkowości.

\footnotetext{
${ }^{7}$ Comparison of Prudence and Matching Principles, Disccusion Memorandum, OECD Working Group on Accounting Standards, Paris 1993.

${ }^{8}$ A. Jaruga, Postęp $w$ harmonizacji standardów rachunkowości w świecie: bariery i nowe problemy, Łódź 1994.
} 
Pierwsza ze wzmiankowanych grup dotyczy przede wszystkim rozwiąań formalnych. Według jej wzoru ujęte są przede wszystkim sposoby prowadzenia ksiąg. Druga obejmuje te zasady, które dotyczą zawartości ksiąg, a więc przede wszystkim będące treścią niniejszego artykułu:

- zasady ewidencjonowania i rozliczeń majątkowych,

- zasady definiowania (określania) wyniku finansowego przedsiębiorstwa.

Ustawa wprowadza też zapis, zgodnie z którym to przedsiębiorstwo (personalnie: jego kierownik) decyduje, jakie zasady będą w nim obowiązywać. To przedsiębiorstwo zatem określa, jakie metody rozliczeń rachunkowościowych będzie stosować w zakresie definiowania wysokości osiaganego przez siebie wyniku finansowego, oraz czy i jaka wysokość zysku bilansowego (lub straty bilansowej) będzie przez nie ,ujawniana”. Kierownik przedsiębiorstwa ponosi też odpowiedzialność za wykonywanie obowiązków w zakresie rachunkowości (art. 4 ust. 5 u.o.r.).

\section{WYKORZYSTANIE ZALEGALIZOWANYCH METOD RACHUNKOWOŚCI W KSZTAŁTOWANIU WYSOKOŚCI WYNIKU FINANSOWEGO}

Zalegalizowane działanie księgowe moga pozytywnie odpowiadać na potrzeby przedsiębiorstwa przez dobór takiej metody rozliczeń księgowych, która umożliwi maksymalny stopień realizacji tych potrzeb.

Z pewnością nie miałby na myśli zalegalizowanej polskiej rachunkowości S. Sauder, pisząc, że rachunkowość dostarcza wiedzy obiektywnej, powszechnie obowiązującej ${ }^{9}$. Informacje ,,produkowane” przez rachunkowość określają wartość będącą logicznym iloczynem faktycznych wyników finansowych przedsiębiorstwa oraz zastosowanych przez nie księgowych metod rozliczeń. $\mathrm{Na}$ wielkość ,faktycznych wyników” rachunkowość nie ma wpływu. Z kolei istnieje dominujący wpływ rachunkowości na drugi ze wspomnianych wyżej elementów. Wybór metody dokonywany jest z zestawu metod dopuszczonych prawnie. Ich wpływ na wynik finansowy ilustruje tabela (s. 155-156).

Zalegalizowana rachunkowość wariantowa charakteryzuje się wielopłaszczyznowością przejawiającą się $\mathrm{w}$ występowaniu zasad:

- o zwerbalizowanym wyborze - na przykład sposoby wyceny rozchodu aktywów obrotowych,

- o wyborze opartym na definicji uogólnionej - na przykład wartość szacowana rezerw,

- o wyborze pomiędzy zwerbalizowaną a uogólnioną definicja - na przykład stopień realizacji umów długoterminowych czy wycena wartości produkcji niezakończonej.

${ }^{9}$ S. Sauder, Knowing What Others Know: Common Knowledge, Accounting and Capital Markers, „Accounting Horizons” 16, nr 4, s. 308 i n. 
Mechanizmy rachunkowości wariantowej sa definicyjnie powiązane z kategoria wyceny i określania wyniku finansowego przedsiębiorstw ${ }^{10}$. Kategoria wyceny wyniku finansowego odgrywa tym większą rolę, im większy jest udział ,,aspektu przewidywań" (szacowania) w procesie organizacji rachunkowości w przedsiębiorstwie. Równocześnie następuje coraz wyraźniejsze odchodzenie od metody wartości według kosztu historycznego na rzecz wyceny według wartości bieżącej (względnie: godziwej ${ }^{11}$ ). Zdaniem A. Wyatta, uzyskuje się $\mathrm{w}$ ten sposób zbliżenie rachunkowości do ekonomii ${ }^{12}$. Skutkiem stosowania tego podejścia jest między innymi tworzenie systemu rezerw w rachunkowości ${ }^{13}$. To słuszne, co do zasady, podejście jest jednak nie w pełni zdefiniowane w prawie bilansowym. Brak jednoznacznego sprecyzowania daje przedsiębiorstwom możliwość księgowego sterowania wynikiem finansowym. To przedsiębiorstwa posiadaja prawo wyboru, czy i kiedy tworzyć będą mechanizmy aktywizujące koszty lub przychody.

Także teoria wartości ekonomicznej przy zastosowaniu mechanizmów rachunkowości wariantowej w określaniu jej wysokości wzbudza szereg wątpliwości. Wynika to z faktu, że obiektywną cechę danego zjawiska lub procesu określa się za pomocą mechanizmów subiektywnych (na przykład analiza pojęcia wartości z metodologicznego i filozoficznego punktów widzenia ${ }^{14}$ ).

Przedsiębiorstwo ma możliwość dowolnego wyboru sposobu określania wartości swoich aktywów oraz wyznaczania swojego wyniku finansowego, zwłaszcza dokonując analizy: stopnia zużycia, przyszłych korzyści ekonomicznych czy też bieżącej wartości rynkowej ${ }^{15}$. Zastosowanie tych mechanizmów powoduje więc, że niegotówkowym składnikom aktywów oraz zobowiązaniom można przypisać po kilka wartości. Różnice w tych „,wartościach” mają wpływ na wynik finansowy.

Rachunkowość w ujęciu obowiązującego polskiego prawa bilansowego stoi też na przeszkodzie poprawnemu -z merytorycznego punktu widzenia - ,odczytywaniu" kondycji finansowej przedsiębiorstwa ${ }^{16}$. Wynika to $\mathrm{z}$ faktu występowania różnych wyników identycznych działań gospodarczych.

${ }^{10}$ Podobnie odnośnie do rachunkowości in definitio m.in.: E. Burzym, Przestanki i perspektywy standaryzacji $i$ międzynarodowej harmonizacji rachunkowości, „Zeszyty Teoretyczne Rady Naukowej SKwP” 23, 1993, s. 7; R. F. Meigs, W. B. Meigs, Financial Accounting, Mc Graw-Hill Publishing Comp., New York 1995, s. 4.

${ }^{11}$ W zakresie kosztów siły roboczej w: M. Dobija, Teoretyczne przestanki wartości godziwej, ,Zeszyty Teoretyczne Rachunkowości” 32, 2006, s. 39-54. Por. również: L. Michalczyk, Zastosowanie metody prognozowanego kosztu jednostkowego $w$ definiowaniu kosztów funkcjonowania przedsiębiorstwa na przyktadzie analizy zatrudnienia, „Nauka i Gospodarka” 2010, nr 7 (4), s. 81-88.

12 A. Wyatt, The SEC Says: Mark to Market!, „Accounting Horizons” 5, 1991, nr 1, s. 83.

13 A. N. Duraj, Rezerwy $w$ sprawozdaniach finansowych przedsiebiorstwa, „Acta Universitatis Lodziensis. Folia Oeconomica” 2004, z. 171, s. 23-42; A. Hajduk, Rezerwy jako element polityki bilansowej przedsiębiorstwa, „Prace Naukowe Katedry Zarządzania Akademii Morskiej w Gdynii” 2003, nr 4, s. 315-332.

${ }^{14}$ A. Mazur, Konkretyzacja filozoficznego znaczenia wartości oraz jej pomiar $w$ rachunkowości, „Zeszyty Teoretyczne Rachunkowości” 41, 2007, s. 143-154.

${ }^{15}$ L. Michalczyk, Metodyka ustalania wysokości wybranych zobowiazań przedsiębiorstw, „Zeszyty Naukowe Towarzystwa Doktorantów Uniwersytetu Jagiellońskiego", Seria: Ekonomia i Zarządzanie 2011, nr 3 (12), s. 47-70.

16 J. Stępniewski, Audyt i diagnostyka firmy, Wydawnictwo Akademii Ekonomicznej im. Oskara Landego we Wrocławiu, Wrocław 2001. 
Decyzje gospodarcze wymagają oceny zdolności jednostki do wypracowywania środków pieniężnych i ich ekwiwalentów oraz oceny terminów i stopnia pewności ich wypracowania ${ }^{17}$. Dowodzi się, że stosowanie tej zasady ma umożliwiać uzyskanie wiarygodnego opisu działań gospodarczych ${ }^{18}$. Nie da się jednak pominąc milczeniem faktu, iż zasada ta prowadzi do tworzenia systemu rezerw, których bieżąca wartość zazwyczaj jest różna od wartości efektu końcowego. Umożliwia to przedsiębiorstwom manipulowanie wyceną bieżącą działań, których efekt ostateczny nastąpi w przyszłości ${ }^{19}$. Dzieje się tak, ponieważ poprawność zastosowania zasady memoriałowej oznacza, że ujęcie skutków zdarzenia w wyniku finansowym ma miejsce niezależnie od tego, czy fakt ten jest udokumentowany w sposób jednoznaczny (na przykład fakturą czy rachunkiem), czy też jedynie oszacowany.

$\mathrm{W}$ celu wyceny aktywów i zobowiązań stosuje się jedno $\mathrm{z}$ czterech rozwiązań ${ }^{20}$ opartych na: koszcie historycznym, koszcie bieżącym, wartości realizacji, wartości bieżącej.

W koszcie historycznym aktywa wyceniane są w kwocie gotówki lub jej ekwiwalentów wydatkowanych w momencie nabycia lub wartości godziwej ${ }^{21}$ przekazanych zasobów w celu ich nabycia. Zobowiązania w tym modelu ujmowane sa $\mathrm{w}$ kwocie świadczeń otrzymanych $\mathrm{w}$ zamian za podjęcie zobowiązania lub $\mathrm{w}$ kwocie gotówki albo jej ekwiwalentów przewidywanych do zapłacenia przy rozliczeniu zobowiązania w przyjętym za typowy toku działalności gospodarczej.

Koszt bieżacy ujmuje aktywa wyceniane w kwocie gotówki lub jej ekwiwalentów, jaka musiałaby być zapłacona, jeśli identyczne lub ekwiwalentne dobra byłyby nabyte. Z kolei zobowiązania wycenia się $\mathrm{w}$ wartości niezdyskontowanej, jaka byłaby $\mathrm{w}$ danej chwili poniesiona $\mathrm{w}$ celu ich uregulowania.

Wartość realizacji (rozliczenia) wycenia aktywa w kwocie gotówki lub jej ekwiwalentów, która uzyskano by ze sprzedaży aktywów w typowym trybie działalności gospodarczej przedsiębiorstwa. Zobowiązania sa tu wyceniane $\mathrm{w}$ wartościach rozliczeniowych, czyli niezdyskontowanych kwotach gotówki lub jej ekwiwalentów przewidywanych do zapłacenia przy rozliczeniu zobowiązania w typowym trybie działalności gospodarczej.

Aktywa wyceniane w wartości bieżącej obejmuja zdyskontowane wartości przyszłych wpływów pieniężnych netto, przewidywanych do uzyskania

${ }^{17}$ Framework for the Preparation and Presentation of Financial Statements, IASC 1989, par. 13 i 15.

${ }^{18}$ M.in. przeprowadzone w latach 1988-1989 w Wielkiej Brytanii badania empiryczne wykazały, że rachunkowość oparta na zasadzie memoriałowej stanowi użyteczniejszą bazę do podejmowania decyzji inwestycyjnych niż rachunkowość oparta na podejściu gotówkowym - za: R. M. Board, J. F. S. Day, The Informative Content of Cash Flow Figurer, ,Accounting and Business Research” 1989, Autumn, s. 3-11; podobnie m.in. A. J. Tracy, Sprawozdania finansowe firm, Warszawa 1996, s. 19.

${ }^{19}$ L. Michalczyk, op. cit.

${ }^{20}$ Opracowano na podstawie wytycznych IASB. Należy jednak zaznaczyć, że poza przedsiębiorstwami, które sporządzają sprawozdawczość na gruncie MSR i MSSF, obowiązuje wycena według wartości rynkowej, a przy jej braku - wartości godziwej.

${ }^{21}$ M. Jędrzejczyk, Dyskonto w szacowaniu wartości godziwej, ,Zeszyty Naukowe”, nr 691, Akademia Ekonomiczna w Krakowie 2006, s. 43-52. 
w typowym trybie działalności gospodarczej ${ }^{22}$. Zobowiązania są wyceniane w bieżącej zdyskontowanej wartości przyszłych wydatków pieniężnych netto, jakie według oczekiwań będą wymagane do uregulowania w typowym trybie działalności gospodarczej.

Do określenia wartości przedsiębiorstwa oraz jego osiagnięć ekonomicznych i sytuacji finansowej używa się odmiennych kategorii finansowych, przy czym kluczowe znaczenie mają: przychody, zyski, koszty, straty, obciążenia. $\mathrm{Sa}$ to kategorie również przypisane do pomiaru rentowności działalności gospodarczej i określają stopień korzyści finansowych z prowadzonych działań gospodarczych.

Efekt pomiaru działań gospodarczych przedsiębiorstwa odnosi się do określonego czasu (okresu sprawozdawczego). Dla ustalonego wyniku okresu sprawozdawczego kategoriami pierwotnymi sa przychody i koszty. Sposób ich określenia podlega zasadom ujętym w u.o.r.

Przychód definiowany jako wzrost korzyści ekonomicznych w okresie sprawozdawczym wymaga równoczesnego wystąpienia poniższych warunków:

- uprawdopodobnienia,

- wiarygodnego (opartego na akceptowanych metodach rachunkowości) określenia jego wartości,

- skutku w postaci wzrostu kapitału własnego lub zysku do podziału w sposób inny niż wniesienie środków przez udziałowców albo właścicieli.

Oznacza to, że przychód jest przyrostem aktywów lub zmniejszeniem zobowiązań inną drogą niż dokapitalizowanie.

$\mathrm{Z}$ powyższych działań, w zakresie tematyki nieniejszego artykułu znaczenie mają rozwiązania wpływające na wielkości przychodów i kosztów bilansowych. Zasadniczymi cechami tych działań są:

- „rolowanie kosztów” z wykorzystaniem procedur umożliwiających „,blokowanie kosztów" (w ramach zwiększania wyniku bilansowego),

- ,przyspieszanie ujawniania przychodów” z wykorzystaniem rozliczeń RMP opartych na nieweryfikowalnych na dzień bilansowy, założeniach a priori.

W tym zakresie u.o.r. dopuściła rozwiązania dotyczące (por. tabela, s. $155-156)$ ):

- środków trwałych,

- wartości niematerialnych i prawnych,

- zapasów,

- rozliczenia produkcji,

- klasyfikacja leassingów,

- rozliczenia umów długoterminowych,

- należności i zobowiązań oraz ich aktualizacji,

- podatku dochodowego odroczonego,

- bilansowych kosztów i przychodów finansowych, oraz działania wykorzystujące rozwiązania podatkowe, w zakresie powiązań rachunkowości z prawem podatkowym w aspektach:

- rozliczania środków trwałych,

${ }^{22}$ Por. P. J. Liang, Recognition: An Information Content Perespective, „Accounting Horizons” 15, 2001, nr 3, s. 223. 


\section{Tabela}

Instrumenty zalegalizowanej rachunkowości wariantowej wpływające na powstanie różnic w wyniku finansowym

\begin{tabular}{|c|c|c|c|c|c|c|}
\hline \multirow[t]{2}{*}{ Lp } & \multicolumn{3}{|c|}{ Bilans } & \multicolumn{2}{|c|}{ Wpływ na przejściowy wynik finansowy } & \multirow[b]{2}{*}{ Kategoria } \\
\hline & Kategoria & Pozycja & Rodzaj & in plus & in minus & \\
\hline $1 \mathrm{a}$ & Aktywa & $\begin{array}{l}\text { Rzeczowe } \\
\text { aktywa } \\
\text { trwałe }\end{array}$ & Środki trwałe & $\begin{array}{l}\text { maksymalne koszty } \\
\text { zakupu - aktywowa- } \\
\text { ne w wartości środka } \\
\text { trwałego; minimalna } \\
\text { wartość wyposażenia } \\
\text { (nieskocenne środki } \\
\text { trwałe); uwzględnie- } \\
\text { nie wartości rezydu- } \\
\text { alnej }\end{array}$ & $\begin{array}{l}\text { minimalna cena na- } \\
\text { bycia; maksymalna } \\
\text { granica wartości wy- } \\
\text { posażenia (niskocen- } \\
\text { nych środków trwa- } \\
\text { łych); } \\
\text { rezygnacja z usta- } \\
\text { lania wartości rezy- } \\
\text { dualnej }\end{array}$ & OT - wartość \\
\hline \multirow[t]{3}{*}{$1 b$} & & & & $\begin{array}{l}\text { brak odpisów aktua- } \\
\text { lizacyjnych z tytułu } \\
\text { trwałej utraty war- } \\
\text { tości }\end{array}$ & $\begin{array}{l}\text { stosowanie aktuali- } \\
\text { zacji wartości }\end{array}$ & LT - wartość \\
\hline & & & & $\begin{array}{l}\text { metodar liniowa; } \\
\text { maksymalny okres } \\
\text { użytkowania księgo- } \\
\text { wego }\end{array}$ & $\begin{array}{lr}\text { metoda degresywna; } \\
\text { minimalny } & \text { okres } \\
\text { księgowego użytko- } \\
\text { wania }\end{array}$ & $\mathrm{AM}$ \\
\hline & & WNIP & Goodwill & maksymalny okres & minimalny okres & $\mathrm{AM}$ \\
\hline \multirow[t]{2}{*}{$1 \mathrm{c}$} & & & $\begin{array}{l}\text { Koszty prac } \\
\text { rozwojowych }\end{array}$ & $\begin{array}{l}\text { maksymalny zakres } \\
\text { aktywowania kosz- } \\
\text { tów wytworzenia }\end{array}$ & $\begin{array}{l}\text { koszty wytworzenia } \\
\text { na poziomie kosztów } \\
\text { bezpośrednich }\end{array}$ & OT - wartość \\
\hline & & & & $\begin{array}{l}\text { brak odpisów aktua- } \\
\text { lizujących przy utra- } \\
\text { cie przydatności eko- } \\
\text { nomicznej }\end{array}$ & $\begin{array}{l}\text { odpisy aktualizujące } \\
\text { przy utracie przy- } \\
\text { datności ekonomicz- } \\
\text { nej }\end{array}$ & LT - wartość \\
\hline \multirow[t]{3}{*}{2} & & $\begin{array}{l}\text { Rzeczowe } \\
\text { aktywa } \\
\text { obrotowe }\end{array}$ & Zapasy & $\begin{array}{l}\text { cena nabycia; mak- } \\
\text { symalne rozbudo- } \\
\text { wanie kosztów pro- } \\
\text { dukcyjnych pośred- } \\
\text { nich przypisanych; }\end{array}$ & $\begin{array}{l}\text { cena zakupu; wy- } \\
\text { odrębnianie grup } \\
\text { nieuzasadnionych } \\
\text { kosztów produkcyj- } \\
\text { nych }\end{array}$ & $\begin{array}{l}\text { wycena } \\
\text { przychodu }\end{array}$ \\
\hline & & & & $\begin{array}{l}\text { wzrost cen w tym } \\
\text { asortymancie: FIFO, } \\
\text { spadek:LIFO; wyko- } \\
\text { rzystanie cen ewi- } \\
\text { dencyjnych }\end{array}$ & $\begin{array}{l}\text { wzrost cen: LIFO, } \\
\text { spadek cen: FIFO; } \\
\text { wykorzystanie cen } \\
\text { ewidencyjnych }\end{array}$ & $\begin{array}{l}\text { wycena } \\
\text { rozchodu }\end{array}$ \\
\hline & & & & ograniczana & maksymalizowana & $\begin{array}{l}\text { aktualizacja } \\
\text { wyceny }\end{array}$ \\
\hline
\end{tabular}


cd. tabeli

\begin{tabular}{|c|c|c|c|c|c|c|}
\hline \multirow[t]{2}{*}{ Lp. } & \multicolumn{3}{|c|}{ Bilans } & \multicolumn{2}{|c|}{ Wpływ na przejściowy wynik finansowy } & \multirow[b]{2}{*}{ Kategoria } \\
\hline & Kategoria & Pozycja & Rodzaj & in plus & in minus & \\
\hline & \multirow[t]{9}{*}{$\begin{array}{l}\text { Aktywa } \\
\text { i pasywa }\end{array}$} & \multirow{9}{*}{\begin{tabular}{|l} 
Niefinan- \\
sowe \\
aktywa \\
obrotowe \\
i ,,pasy- \\
wowe” \\
oraz RMK \\
i rezerwy
\end{tabular}} & Należności & $\begin{array}{l}\text { wycena według war- } \\
\text { tości aktualnej (no- } \\
\text { minalna + odsetki) }\end{array}$ & $\begin{array}{l}\text { wycena według war- } \\
\text { tości historycznej }\end{array}$ & $\begin{array}{l}\text { odsetki } \\
\text { bilansowe }\end{array}$ \\
\hline & & & $\begin{array}{l}\text { RMK - } \\
\text { bierne/czynne }\end{array}$ & $\begin{array}{l}\text { maksymalny czas } \\
\text { rozliczenia kosztów }\end{array}$ & $\begin{array}{l}\text { zaliczanie maksy- } \\
\text { malnych kosztów do } \\
\text { kosztów okresu } \\
\text { (łącznie z rezygnacją } \\
\text { tworzenia RMK } \\
\text { czynnych) }\end{array}$ & RMK czynne \\
\hline & & & & \begin{tabular}{|l} 
stosowanie \\
w ograniczonym \\
zakresie
\end{tabular} & $\begin{array}{l}\text { maksymalne } \\
\text { zastosowanie }\end{array}$ & RMK bierne \\
\hline & & & Rezerwy & -j.w.- & -j.w.- & $\begin{array}{l}\text { analog. do } \\
\text { RMK - b. }\end{array}$ \\
\hline & & & \multirow{2}{*}{$\begin{array}{l}\text { Umowy } \\
\text { i kontrakty } \\
\text { długotermi- } \\
\text { nowe }\end{array}$} & metodą procentową & $\begin{array}{l}\text { metodą zakończenia } \\
\text { kontraktu }\end{array}$ & naliczanie \\
\hline & & & & brak uznawania & uznawanie & $\begin{array}{l}\text { rezerwa } \\
\text { z tytułu straty } \\
\text { na kontrakcie }\end{array}$ \\
\hline & & & Zobowiązania & $\begin{array}{l}\text { wycena w wartości } \\
\text { nominalnej }\end{array}$ & naliczenie & $\begin{array}{l}\text { odsetki } \\
\text { bilansowe }\end{array}$ \\
\hline & & & \multirow[t]{2}{*}{$\begin{array}{l}\text { Odroczony } \\
\text { podatek } \\
\text { dochodowy }\end{array}$} & $\begin{array}{l}\text { wykorzystanie } \\
\text { wszelkich ujemnych } \\
\text { różnic przejściowych }\end{array}$ & $\begin{array}{l}\text { oparcie się na zasa- } \\
\text { dzie ostrożności } \\
\text { - wykorzystanie } \\
\text { ujemnych różnic } \\
\text { przejściowych, } \\
\text { których prawdopo- } \\
\text { dobieństwo przyspo- } \\
\text { rzenia przedsiębior- } \\
\text { stwu korzyści gra- } \\
\text { niczy z pewnością }\end{array}$ & $\begin{array}{l}\text { ujemne } \\
\text { różnice } \\
\text { kursowe }\end{array}$ \\
\hline & & & & uwzględniana & nieuwzględniana & $\begin{array}{l}\text { strata } \\
\text { podatkowa } \\
\text { z lat ubiegłych }\end{array}$ \\
\hline
\end{tabular}

WNIP - wartości niematerialne i prawne, RMK - rozliczenia międzyokresowe kosztów, OT - dokument wprowadzający środki trwałe i wnip do ewidencji środków trwałych i ksią, LT - dokument „wyprowadzający” środek trwały z ewidencji księgowej, likwidacja środka trwałego, AM - amortyzacja

Adnotacje tabelaryczne: 1) Tu: wynik finansowy okresu sprawozdawczego mającego miejsce przed całkowita aktywizacja kosztowa względnie przychodowa poszczególnej pozycji bilansu; 2) Obecnie, w nawiązaniu do ustaw prawa podatkowego: 3500,00 PLN, (3) Racjonalizacja prac księgowych wskazuje na potrzebę tworzenia RMK czynnych co najmniej w tych pozycjach, które maja wpływ na rozliczenia podatkowe. Stosując optymalizację rozliczeń podatkowych w przedsiębiorstwie, może to oznaczać klasyfikowanie RMK czynnych na ostatni dzień okresu sprawozdawczego.

Źródło: opracowanie własne na podstawie u.o.r. 
- rozliczania zapasów,

- określania wartości produkcji,

- określania wartości realizacji umów długoterminowych ${ }^{23}$.

Wymienione wyżej grupy rodzajowe aktywów i pasywów oraz „działań”, których rozróżnienia dokonano ze względu na specyficzne sposoby klasyfikacji i rozliczania, można podzielić ze względu na wpływ na wynik finansowy na:

1) klasyfikowane według wartości początkowej - im jest ona wyższa, tym niższe są koszty okresu, wyższy wynik bilansowy i potencjalnie większa wartość „kosztów rolowanych”, o ile ich rozliczanie następować będzie w przyszłych okresach sprawozdawczych. W grupie tej wyszczególnić można: aktywa trwałe (łącznie $\mathrm{z}$ inwestycjami $\mathrm{w}$ środki trwałe $\mathrm{i}$ wartości niematerialne $\mathrm{i}$ prawne), zapasy (łącznie z produkcją niezakończoną), umowy długoterminowe, naliczanie bilansowych przychodów i kosztów finansowych, podatek dochodowy odroczony ${ }^{24}$;

2) wynikające $z$ wyboru metody rozliczenia kosztowego - im okres rozliczania jest dłuższy (z wyjątkiem nierównej wartości umorzenia i amortyzacji aktywów trwałych), tym wielkość bieżącego wyniku bilansowego jest wyższa. Wyjątek stanowi tu amortyzacja/umorzenie metodą degresywną lub nieakceptowana przez prawo podatkowe, na przykład metodą jednostek produkcyjnych. Dotyczy to w szczególności umorzenia i amortyzacji aktywów trwałych;

3) będące konsekwencją wyboru sposobu wartościowania rozliczenia - uzależnione jest od rotacji składników aktywów. Im rotacja danego składnika aktywów jest mniejsza, tym bardziej podniesienie jego wartości skutkować może zwiększeniem wyniku finansowego, pod warunkiem jednak przyjęcia cen ewidencyjnych jako metody rozliczeń zapasów. Im wyższy jest udział wartościowy składników słabo rotujących, tym większe znaczenie ma metoda cen ewidencyjnych w tworzeniu zysku bilansowego w bieżącym okresie sprawozdawczym. Obejmuje też zakres wyboru metody rozliczeń zapasów w korelacji $\mathrm{z}$ rozliczeniem produkcji, $\mathrm{w}$ tym przede wszystkim produkcji niezakończonej.

${ }^{23}$ Por. E. Jabłońska-Kośmider, Środki trwałe $w$ świetle przepisów bilansowych $i$ podatkowych, „Zeszyty Naukowe Katedry Nauk Ekonomicznych” nr 1-2, Wyższa Szkoła Ekonomii i Administracji w Bytomiu, 2003-2004, s. 111-122.

${ }^{24}$ Szerzej prace: L. Michalczyk, Finansowe sposoby rozliczeń zapasów magazynowych $w$ aspekcie bilansowym $i$ podatkowym, w: J. Lewandowski (red.), Zarzadzanie organizacjami gospodarczymi. Koncepcje i metody, Wydawnictwo Politechniki Łódzkiej, t. 1, Łódź 2007; idem, Przekwalifikowywanie aktywów finansowych, w: B. Micherda (red.), Sprawozdawczość i rewizja finansowa w ksztattowaniu wiarygodności informacji ekonomicznej, UE w Krakowie, Kraków 2005; idem, Rola cen wewnętrznych $w$ rozrachunku wewnętrznym wielopoziomowych jednostek gospodarczych $w$ aspekcie transferu kapitatu za granice, w: K. Gomółka (red.), Wspótpraca transgraniczna a rozwój regionalny, Instytut Ekonomiczny PWSZ w Elblągu, Warszawa 2006; idem, Rola umorzenia aktywów trwałych $w$ powstaniu różnic wyniku finansowego, ,Zeszyty Naukowe Towarzystwa Doktorantów Uniwersytetu Jagiellońskiego” 2007, Seria Ekonomia i Zarządzanie, $\mathrm{nr}$ 2; idem, Rozliczenie produkcji pomocniczej $w$ aspekcie rozrachunku wewnętrznego przedsiębiorstw $w$ realiach polskich, w: E. Tabaszewska, B. Radawski (red.), Nowoczesne koncepcje zarzadzania - teoria $i$ praktyka, Wydawnictwo AE we Wrocławiu, Wrocław 2006; idem, Rozliczenia zapasów magazynowych $w$ aspekcie efektywności ekonomicznej podmiotów gospodarczych $w$ polskich realiach, w: T. Wawak, W. Szarapa (red.), Projekty i realność gospodarcza, Wydawnictwo Informacji Ekonomicznej UJ, Kraków 2005; idem, Umorzenie a amortyzacja $w$ aspekcie rachunkowościowej ochrony obrotu gospodarczego, w: B. Micherda (red.), Rachunkowość w ochronie obrotu gospodarczego, Wydawnictwo AE w Krakowie, Kraków 2005; idem, Wiarygodność kalkulacji kosztów produkcji w świetle opcyjnych rozwiazań polskiego prawa bilansowego, w: VI Ogólnopolskie Seminarium Doktorskie Rachunkowości i Finansów, WSRiF w Sopocie, Sopot 2006. 
W zakresie środków trwałych nieprecyzyjny język unormowań rachunkowości daje przedsiębiorstwom:

1) możliwość wyboru określania składników wartości środka trwałego, przede wszystkim przyjmowanego za środek trwały w budowie, w tym definiowania kosztów partii próbnej lub partii testowej, pierwsze klasyfikując do kosztów okresu bądź wartości zapasów (przy uznaniu ich za pełnowartościowe), drugimi - zwiększając wartość środka trwałego. Od momentu przyjęcia na stan środków trwałych, który to moment wynika $\mathrm{z}$ decyzji przedsiębiorstwa, zależy, jaka wielkość wydatków będzie kosztem, a jaka zwiększy wartość środka trwałego w budowie;

2) możliwość wyboru sposobu kalkulacji wartości wytwarzanego środka trwałego we własnym zakresie. Stosowane rozwiązania dopuszczają wybór obok w ,,stały” sposób akceptowanego kosztu transportu środka trwałego:

- kosztu materiałów i energii,

- kosztu materiałów, energii i robocizny bezpośredniej,

- kosztu materiałów, energii, robocizny bezpośredniej oraz narzut kosztów ogólnego zarządu (w różnych wersjach jego przeliczania);

3) możliwość wyboru zakresu i sposobu określania technologicznej różnicy między ulepszeniem (modernizacją) a remontem zwłaszcza wówczas, gdy remont obejmuje wymianę starszych technologicznie składników środka trwałego;

4) możliwość wyboru zakresu i sposobu podziału łącznych kosztów kilku działań inwestycyjnych w sytuacji, gdy nie podlegają one lub podlegają różnym stawkom amortyzacyjnym, na przykład związanych z gruntem i jego zabudowa, skomputeryzowaniem produkcyjnych linii technologicznych, transportem specjalistycznym i ogólnego zastosowania;

5) możliwość wyboru wykorzystania tak zwanej wartości godziwej w sytuacji, gdy jest ona różna od wartości przyjmowanego środka trwałego w budowie do środków trwałych jako „doszacowanie” wartości środka trwałego;

6) możliwość wyboru wykorzystania prawa do zmiany metody amortyzacji bilansowej $\mathrm{w}$ stosunku do niezmiennej amortyzacji podatkowej $\mathrm{w}$ oparciu o tak zwaną zmianę sposobu czerpania korzyści ekonomicznych $\mathrm{z}$ danego środka trwałego. Przedsiębiorstwo może więc wydłużać okres amortyzacji bilansowej stosując na przykład procedury „doszacowywania” wartości środków trwałych ${ }^{25}$;

7) dowolność w ustalaniu utraty wartości środka trwałego zwłaszcza poniżej jego ceny sprzedaży netto;

8) możliwość wyboru specyfiki rozliczeń środka trwałego w ramach jego sprzedaży i odsprzedaży. W razie współpracy podmiotów gospodarczych u.o.r. nie uniemożliwia wykorzystania ,przerzutu” kosztów za pomoca sprzedaży i odsprzedaży tego samego środka trwałego. W tym wypadku środek trwały zaczyna funkcjonować w nowej wartości netto. Podobna sytuacja występuje

25 Jakkolwiek jest to podejście w założeniach słuszne, nasuwa się pytanie dotyczące sensu podziału kosztów materiałowych związanych z danym środkiem trwałym. Skoro wskazany jest proces doszacowywania, to nie ma powodu, żeby rozróżnić koszty remontów i modernizacji, jeśli i tak wartość całkowitych wydatków materiałowych byłaby korygowana o różnicę w kosztach przy doszacowywaniu. Jest to więc pozbawione głębszego sensu dublowanie prac księgowych. 
w wypadku przekazania między podmiotami różnych gruntów w wieczyste użytkowanie (na przykład droga aportu „,wzajemnego”). Sprzedaż z odsprzedażą może też być wykorzystywana przy zarządzaniu bieżącymi zobowiązaniami podatkowymi;

9) dowolność w wycenie wartości niematerialnych i prawnych (wnip) w cenie nabycia (definicja: art. 28 ust. 2 u.o.r.) lub koszcie wytworzenia. Równocześnie przedsiębiorstwo może wprowadzać wartości niematerialne i prawne w wybrany przez siebie składnik bilansu. Wnip moga być zaliczone w skład aktywów, jeśli zostały przez przedsiębiorstwo nabyte, w innych wypadkach stanowią element czynnych RMK. Wyjątek stanowią tu składniki działalności produkcyjnej (produkt) podstawowej przedsiębiorstwa oraz oprogramowanie komputerowe wytworzone na własne potrzeby, a będące też przedmiotem sprzedaży przez to samo przedsiębiorstwo. W tym ostatnim przypadku określane jest przez różnicę kosztu sprzedaży i wartości sprzedaży, a klasyfikowane jako składnik kosztów okresu ${ }^{26}$. Istotne są też tu rozbieżności między prawem bilansowym a podatkowym $\mathrm{w}$ zakresie określania wartości w wypadku wnip przejętych drogą darowizny. W pierwszym wypadku ich wartość jest równa „,”, w drugim - odpowiada cenie rynkowej;

10) wynikającej $\mathrm{z}$ dowolności przy podziale wydatków między wartość środka trwałego a wnp koszty prac rozwojowych czy goodwill (wartość firmy). Następstwem może być różny poziom amortyzacji wzmiankowanych wydatków ze względu na możliwe różne stawki;

11) możliwość wyboru jednego spośród trzech sposobów wyliczania kosztów wnip dotyczących na przykład prac rozwojowych:

- koszt wytworzenia, dopuszczający też cześć kosztów pośrednich produkcyjnych, gdy wytwarzane sa we własnym zakresie,

- koszty bezpośrednie, gdy wytwarzanie następuje z użyciem materiałów obcych czy usług zewnętrznych.

Takie rozróżnienie, gdy na przykład nabycie materiałów biurowych jest fakultatywnie ,dopisywane” do wartości danych prac rozwojowych, powoduje, że sposób ich kalkulacji znajduje się w dużym stopniu w gestii przedsiębiorstwa;

12) wynikającą z zapisów art. 33 ust. 2 u.o.r. dużą dowolność w definiowaniu tego, co jest ,pracą badawczą” (koszty okresu), ,,pracą rozwojową kwalifikowaną" (wnip, aktywa, amortyzacja/umorzenie) czy ,,pracą rozwojową niekwalifikowana" (koszty okresu). Jest to tym bardziej uzasadnione, że te dwie ostatnie kategorie sa wyznaczane a priori w stosunku do „dnia sprawozdawczego”. Oznacza to, że przedsiębiorstwo może wydatki poniesione uznać za:

- koszt w momencie ich ponoszenia, jeśli przedsiębiorstwo chce zdefiniować ten aspekt swej działalności jako „,prace badawcze”,

- jednorazowy koszt $\mathrm{w}$ momencie zakończenia prac, jeśli przedsiębiorstwo dojdzie do wniosku, że prace te nie spełniły swych założeń (nie zrealizowano zakładanego celu),

${ }^{26}$ Szerzej zob. R. Dyląg, Zasady ujmowania przychodów i kosztów specyficznych dla firm branży IT $w$ świetle ustawy o rachunkowości, MSR/MSSF $i$ US GAAP, „Zeszyty Teoretyczne Rachunkowości” 39, 2007, s. 21-32. 
- koszt amortyzacji, jeśli przedsiębiorstwo uzna, że spełniają one lub w jakiejś mniej lub bardziej „,mglistej” przyszłości spełnią swe założenia.

Przedsiębiorstwo może też je sobie podzielić na grupy według powyższych założeń. To przedsiębiorstwo decyduje więc, jaka część poniesione przez nie wydatków i kiedy będzie dla niego kosztem.

Działania te mogą być też ,ukryte” jako element ,produkcji w toku” (a więc: zapasów). Na podstawie polskich przepisów bilansowych nie można zakwestionować takiego podejścia, które przy badaniu bilansu danego okresu sprawozdawczego, ale przeprowadzonego w kolejnym roku (latach) ,,zostaje rozmyte”;

13) wykorzystanie kategorii godwill w operacjach „nabycia rzeczowego” we wzajemnie powiązanych przedsiębiorstwach. Dzięki temu następuje „,przesunięcie" wyniku bilansowego między przedsiębiorstwami;

14) dowolność w ustalaniu okresu amortyzacji godwill i prac rozwojowych (obie: amortyzacja do 5 lat). $\mathrm{W}$ tym zakresie jednoznacznie określono jedynie metodę amortyzacji godwill (metoda liniowa);

15) wyciągnięcia korzyści z braku sprecyzowania terminu ,znaczącej części spodziewanych korzyści”. Ich brak mógłby być motywem zastosowania odpisu z tytułu trwałej utraty wartości wnip. To określenie u.o.r. posiada dwie grupy nieścisłych i nieprecyzyjnych zagadnień:

- ,znacząca część”,

- „,spodziewane korzyści”;

16) dowolność przekwalifikowywania zapasów na przydatne i zbędne z możliwością ich późniejszego ponownego przekwalifikowywania. W wypadku działalności sezonowej, przedsiębiorstwo samo będzie ustalać: czy, kiedy i jakie zapasy uzna za zbędne, by później ponownie je przekwalifikować. Za każdym razem rozlicza koszty, przy drugim razie może przyjąć wartość w cenie sprzedaży netto, która może być różna od pierwotnego kosztu wytworzenia. To rozwiązanie ma duże znaczenie, zwłaszcza jeśli przełom okresów sprawozdawczych przypada na okres ,trwania sezonu”;

17) możliwość wyboru metody wyceny zapasów w cenie rzeczywistej lub ewidencyjnej. Ta druga kategoria oznacza pojawienie się przy rozchodzie wartości odchyleń. Najczęściej stosowane metody ich rozliczeń bazują na proporcji do całości rozchodu. Oznacza to, że zwiększając zyski, należy maksymalizować wartość słaborotujących zapasów, a przy odwrotnym celu działań - zmniejszać ich wartość. Efekt można maksymalizować przy uwzględnieniu stosowanej metody rozchodu zapasów. Przedsiębiorstwo posiada dowolność w przypisywaniu wartości ceny ewidencyjnej do poszczególnych składników zapasów.

18) możliwość wyboru metody rozchodu zapasów spośród: FIFO, LIFO, średniej ważonej (przeciętnej) oraz szczegółowej identyfikacji. Poza tą ostatnią, w wypadku stosowania ceny rzeczywistej wszystkie dają możliwość wykorzystania w procedurze zgodnego $\mathrm{z}$ litera prawa kreowania wyniku finansowego;

19) możliwość dokonywania dowolnej weryfikacji czynników wpływających na obniżenie wartości aktywów obrotowych co skutkuje dowolnością w zakresie wartościowania odpisów aktualizujących. Ustawa umożliwia „manipulowanie” wartością odpisów w oparciu o art. 35c u.o.r. Zarówno o przyczynie odpisu, poza przypadkami tak ewidentnymi, jak upadłość kontrahenta, jak i o jej ustaniu 
decyduje przedsiębiorstwo, przy czym kosztem podatkowym są jedynie odpisy $\mathrm{z}$ tytułu przeterminowania zapasów, likwidacji kontrahenta lub w wyniku rozpraw sądowych z kontrahentami dotyczącymi nieziszczenia zapłaty, przy zachowaniu warunku wcześniejszego zakwalifikowania ich do przychodów podatkowych;

20) możliwość wyboru metod kalkulacji kosztów produkcji ${ }^{27}$ zwłaszcza w zakresie:

- produkcji masowej-kalkulacja podziałowa prosta lub ze współczynnikami albo doliczeniowa-asortymentowa,

- produkcji „krótkoseryjnej” lub jednostkowej - kalkulacja doliczeniowa asortymentowa lub zleceniowa.

Każda z tych metod znaleźć może zastosowanie w zależności od sposobu i zakresu definiowania podziału na koszty bezpośrednie (przypisane) oraz pośrednie (przypisane i nieprzypisane) ${ }^{28}$. Przy czym te ostatnie moga być uwzględniane $\mathrm{w}$ indywidualnie dobranym sposobie rozliczania narzutu. Moga dawać one odmienne kwoty kosztów transferowanych w wartości przyszłego zapasu.

Z kolei „manewrowaniu” momentem ujęcia kosztów służyć może metoda półfabrykatowa $\mathrm{z}$ grupy kalkulacji wielostopniowej (fazowej). W wypadku bieżących wahań tak zwanych cen rynkowych przedsiębiorstwa mogą stosować kalkulację podziałowa $\mathrm{w}$ procesach sprzężonych. Połączenie jej $\mathrm{z}$ cenami ewidencyjnymi pozwala na uzyskanie efektu stymulacji wyniku w kierunku pożądanym przez przedsiębiorstwo. U.o.r. dopuszcza również stosowanie kategorii kosztów docelowych $\mathrm{w}$ powiązaniu $\mathrm{z}$ wartościowaniem zapasów według cen ewidencyjnych ${ }^{29}$.

Jedynie grupy tak zwanych produktów wielokrotnej sprzedaży maja bardziej jednoznaczny sposób kalkulacji. Są one też precyzyjnie zidentyfikowane (art. 34 ust. 3 u.o.r.);

21) możliwość „,manipulacji kalendarzowych” tak zwanym normalnym poziomem wykorzystania zdolności produkcyjnych, w zależności od sposobu definiowania okresu oraz wydajności zmiany;

22) osiągnięcie korzyści z zapisu art. 28 ust. 4 u.o.r., który daje możliwość zwiększania kosztów produktów, a więc i zmniejszania kosztów okresu rozliczanych inaczej niż przez rozchód zapasów. Ustawodawca w u.o.r. nie zdefiniował terminu ,długotrwały”. Wykorzystanie tego zapisu u.o.r. ma sens w wypadku produktów słaborotujących lub takich, których sezon produkcji przypada na okres bliski końcowi okresu sprawozdawczego ${ }^{30}$. W przeciwnym razie nie uzyskuje się efektu „transferu kosztów”. Ograniczenia wprowadza

\footnotetext{
${ }^{27}$ Por. J. Gierusz, Poziom wyceny wyrobów gotowych w świetle definicji aktywów, „Prace i Materiały Wydziału Zarządzania Uniwersytetu Gdańskiego” 2006, z. 4, s. 31-40; P. Wójtowicz, Koszt wytworzenia produktów $w$ ustawie o rachunkowości $i$ międzynarodowych standardach rachunkowości, „Prace Naukowe Wyższej Szkoły Przedsiębiorczości i Marketingu”, nr 7, Chrzanów 2003, s. 109-124.

${ }^{28}$ A. Piosik, Uzasadniona część pośrednich kosztów wytworzenia, ,Zeszyty Teoretyczne Rachunkowości" 22, 2004, s. 41-64.

${ }^{29}$ Por. B. Zackiewicz, Cele i funkcje zarzadzania kosztami nowego produktu poprzez koszty docelowe, „Prace i Materiały Wydziału Zarządzania Uniwersytetu Gdańskiego” 2006, z. 4, s. 175-198.

${ }^{30}$ Por. R. Kowalik, Wartość zapasów produktów gotowych wedtug znormalizowanej ustawy o rachunkowości a wskaźniki finansowe, „Finanse, Bankowość, Rachunkowość” 2005, nr 3, s. 348-355; D. Kusz, Wycena produktów w praktyce, ,Rachunkowość” 56, 2005, nr 2, s. 39-41.
} 
dopiero Ministerialny Standard Rachunkowości (MSR) nr 23, § 4 do tak zwanych dostosowanych składników aktywów, niemniej posługując się równie nieprecyzyjnym określeniem: „znaczny czas niezbędny”. Istotniejsze jest wyłączenie wynikające z MSR $\mathrm{nr} 23, \S 6^{31}$;

23) możliwość wyboru metody wyceny towarów. Przedsiębiorstwa wyceniaja towary według cen nabycia (art. 28 ust. 11 u.o.r.) lub zakupu (art. 34 ust. 1 pkt 1 u.o.r.), co oznacza różnicę w ujęciu części kosztów nabycia. Dodatkowo, w sytuacji posiadania towarów o różnym stopniu rotacji lub nabywanych i rozchodowywanych w różnych okresach sprawozdawczych, może stosować ceny ewidencyjne podchodząc do ich wartości w sposób uznaniowy i manewrując sumą kosztów odchyleń (por. art. 34 ust. 2 u.o.r.);

24) możliwość oceny stopnia realizacji kontraktu długoterminowego ${ }^{32}$, który jest ustalany przez przedsiębiorstwo ${ }^{33}$;

25) wykorzystanie wariantowości ustalania wysokości kosztów kontraktów długoterminowych, co wynika też z ,,ogólnej” wariantowości ustalania kosztów działalności w danym przedsiębiorstwie, a mianowicie:

- czy i w jakich proporcjach narzutu zawiera ona koszty pośrednie, zwłaszcza nieprzypisane,

- czy ujmuje się koszt utraconych możliwości na przykład w wysokości potencjalnych przychodów finansowych w pozycjach, które nie skutkuja kosztem finansowym;

26) stosowanie rozliczeń $\mathrm{z}$ tytułu kontraktów długoterminowych dla każdego dowolnego składnika aktywów, w tym również dla aktywów trwałych. Powstaje więc możliwość wykorzystania zmian i przekwalifikowywania aktywów trwałych w systemie:

- zwiększenia zysku w oparciu o rozliczenia zgodne z metoda ,kkoszt plus” dla aktywów tworzonych w oparciu o umowę kontrahencką,

- w wypadku niezawarcia powyższej - przyjęcie aktywów na stan (OT) i korekta przychodów.

W ten sposób przedsiębiorstwo może uzyskać zwiększenie bieżącego wyniku bilansowego. W tym aspekcie obowiązujące prawo bilansowe umożliwia wykorzystanie procedur „dzielenia” i „łączenia” kontraktów długoterminowych ${ }^{34}$. Działania takie umożliwia MSR nr 11. Fakt ten wynika z wielo-

${ }^{31}$ P. Kabalski, Dylematy ujmowania kosztów finansowania zewnętrznego $w$ kontekście nowelizacji MSR 23, „Zeszyty Teoretyczne Rachunkowości” 41, 2007, s. 131-141; J. Kalinowski, Zasady wyceny niezakończonych kontraktów dtugoterminowych - przeglad polskich regulacji rachunkowości w świetle zapisów Międzynarodowych Standardów Rachunkowości, ,Acta Universitatis Lodziensis. Folia Oeconomica" 2005, z. 191, s. 11-175.

${ }^{32}$ Różnice w pomiarze działań gospodarczych objętych charakterystyką kontraktów długoterminowych w analizie porównawczej systemów MSR i US GAAP, por. m.in. S. Silska-Gembka, Pomiar wyniku finansowego z realizacji kontraktów dtugoterminowych wedtug MSR $i$ US GAAP - analiza porównawcza, „Prace i Materiały Wydziału Zarządzania Uniwersytetu Gdańskiego” 2006, z. 4, s. 123-135; J. Turyna, B. Pułaska-Turyna, E. Karwasińska, Rozliczanie dtugoterminowych umów budowlanych $w$ świetle MSSF, US GAAP oraz polskiego prawa bilansowego - analiza porównawcza, „Zeszyty Teoretyczne Rachunkowości” 34, 2006, s. 91-109.

${ }^{33}$ Ponadto merytorycznie błędnym jest przyjęcie założenia, że przy cenach stałych każdy etap realizowanego kontraktu musi mieć identyczną proporcję przychodów do kosztów.

${ }^{34}$ M. Tatarska, Rachunkowość wspólnych przedsięwzięć w ujęciu teoretycznym $i$ praktycznym, „Zeszyty Teoretyczne Rachunkowości” 38, 2007, s. 215-232. 
znaczności definicji „umowy”, a mianowicie, czy aneks obejmujący „dodatkowe roboty" jest odrębną umową w świetle wspomnianego standardu? Jedynym ograniczeniem dla aneksu jest kolejność logiczno-czasowa: aneks musi być poprzedzony umową, którą koryguje. Ale ta sama zasada dotyczy tak zwanej kolejnej umowy.

Przedsiębiorstwo może sterować wysokością naliczonych przychodów z tytułu umów długoterminowych. Ich realizacja wymaga rozwinięcia jednej $\mathrm{z}$ wersji rachunku kosztów zorientowanych na zarządzanie kontraktami ${ }^{35}$. Szczególnie istotne jest tu wykorzystywanie umów długoterminowych zawartych według cen ustalanych na podstawie metody „koszt plus”. W tej metodzie naliczenie następuje niezależnie od technologicznego stopnia zaawansowania wykonywanej usługi. To przedsiębiorstwo ,indywidualnie określa sobie" wysokość przychodów z tytułu niezakończonej i niezafakturowanej części umowy.

Umowa oparta na stałych cenach wymaga szacowania stopnia zaawansowania robót, jednak szacowanie przeprowadza bezpośrednio zainteresowane nim przedsiębiorstwo. Jeśli przedsiębiorstwo uzna, że nie może w sposób „,wiarygodny” wycenić łącznej wartości przychodów lub przyjmie założenie, iż istnieje prawdopodobieństwo, że nie uzyska korzyśsi $\mathrm{z}$ realizowanego kontraktu, może nawet nie wyceniać kontraktu, traktując poniesione koszty jako koszty okresu. Dopuszczona przez u.o.r. fakultatywność dotyczy tu więc nie tylko wyboru metod naliczenia przychodów, ale nawet przeprowadzania samego naliczenia.

Z drugiej strony kontraktem długoterminowym może być każda usługowa działalność przedsiębiorstwa przekraczająca okres sześciu miesięcy. Przedsiębiorstwo może zakwalifikować do nich wszystkie działania usługowe, których nie zakończono finalnym zafakturowaniem na dzień bilansowy, jeśli „,założyłoby sobie", że potrwają co najmniej 6 miesięcy.

Ponadto prawnie zalegalizowanymi czynnikami służących dowolnemu wartościowaniu działań gospodarczych przedsiębiorstwa są:

- wybór spośród dwóch typów działań o charakterze kaucyjnym. Zarówno kaucja zabezpieczająca, jak i rozliczeniowa nie podlegaja opodatkowaniu, moga być więc stosowane jako alternatywa wobec umów „użyczających” składnik majątku, a powodujących powstanie zobowiązań z tytułu podatku PCC (podatek od czynności cywilnoprawnych). Jakkolwiek ich znaczenie finansowe może być istotne - księgowo traktowane sa ,,pobocznie”.

- brak precyzyjnego ujęcia rozliczenia premii i roszczeń z tytułu kontraktu, zwłaszcza jeśli dotyczą one innych niż wadliwość rozliczeń kontraktowych, na przykład „ogólnej” terminowości wykonania usług.

- różnica w podejściu, w którym leasing jest dla celów podatkowych operacyjnym, a dla bilansowych - finansowym ${ }^{36}$.

${ }^{35}$ Por. J. Kalinowski, Zastosowanie metody Earned Value Management $w$ zarzadzaniu projektami, w: I. Sobańska, P. Czajor, J. Kalinowski, J. Michalak, Rachunkowość w przedsiębiorstwie budowlanym. Kontrakty - planowanie - kontrola, Difin, Warszawa 2006.

${ }^{36}$ Por. I. Dziedziczak, Przeksztatcenie leasingu operacyjnego $w$ finansowy u leasingobiorcy $z$ zastosowaniem komputera, „Finanse, Rynki Finansowe Ubezpieczenia”, Zeszyty Naukowe Uniwersytetu 
- wynikająca z rozliczenia umów leasingu. Pozwalają one na dowolność interpretacji kategorii z kwoty płaconego zobowiązania. Wynika to z różnic w wartości opłaty głównej i części odsetkowej przy wykorzystaniu różnic w metodach (KSR ,Leasing, najem i dzierżawa” ${ }^{37}$ oraz MSR nr 17): równomiernej i degresywnych (między innymi metody sumy numerów okresów, degresywna pełna [wewnętrznej stopy zwrotu] czy degresywna przybliżona).

Powyżej przedstawiono akceptowane zgodnie z polską u.o.r., elementy wpływające na wysokość wykazywanego wyniku finansowego. Liczba możliwości w definiowaniu wyniku finansowego pozwala zdefiniować polską ustawę bilansową jako ,bubel prawny”. Na sprawozdaniach finansowych tworzonych zgodnie z tą ustawą opiera się obrót gospodarczy w Polsce i sprawozdawczość krajowa.

\section{ZAKOŃCZENIE}

Wysoka jakość stanowionego w Polsce prawa, zwłaszcza prawa gospodarczego, winna być naczelnym celem wszystkich organów państwowych. Celem nie tylko artykułowanym, ale również realizowanym. Wadliwość zasad i unormowań tego prawa symbolizuje wariantowość polskiej ustawy o rachunkowości. Ponieważ równocześnie istnieje społeczne przyzwolenie na wykorzystywanie luk w prawie gospodarczym i swoista gra w berka między obligującymi a zobligowanymi, zasady prawa gospodarczego winny być analizowane przez ustawodawcę w celu ciągłego ich udoskonalania ${ }^{38}$. W ciagu ostatnich lat państwo nie podjęło żadnych prac w kierunku uniemożliwienia legalnych działań wykorzystujących mankamenty polskiej ustawy o rachunkowości.

Równocześnie w Polsce od 20 lat tworzone sa zasady etyki kapitalistycznej. Etyka w gospodarce kapitalistycznej przejawia się w propagowaniu działań przenoszących potrzebę maksymalizacji zysku ${ }^{39}$ nad odpowiedzialność moralną za ,etycznie-dyskusyjne” metody jego wypracowywania. Tworzona wersja etyki według założeń gospodarki opartej na koncepcjach liberalizmu kapitalistycznego stwierdza, że etyczne są nie normy współżycia gospodarczego (nieszkodzenie sobie nawzajem), ale brak zakazu prawnego działań. Tymczasem celem prawodawstwa nie jest kształtowanie norm etycznych, ale zapobieganie anomaliom w życiu społecznym bądź też naruszeń społecznego czy kulturowego tabu. Naruszenia tabu nie są równoważne pojęciowo z na-

\footnotetext{
Szczecińskiego 2004, nr 1, s. 241-249; A. Stos, Ujęcie transakcji leasingowych w rachunkowości podatkowej $i$ finansowej, „Studia Ekonomiczne Oddziału Łódzkiego PTE” 2007, nr 1, s. 193-213; E. Jańczyk-Strzała, Kryteria klasyfikacji leasingu na gruncie prawa bilansowego, podatkowego $i$ cywilnego, „Finanse, Bankowość, Rachunkowość” 2005, nr 2, s. 342-346; W. Nastaj, Leasing wedtug ustawy o rachunkowości, „Pieniądz i Więź”, 9, 2006, nr 1, s. 21-25.

${ }^{37}$ Por. M. Turzyński, Krajowy Standard Rachunkowości „Leasing, najem i dzierżawa” - wybrane problemy, „Zeszyty Teoretyczne Rachunkowości” 42, 2008, s. 323-334.

${ }^{38}$ Por. szerzej L. Michalczyk, Etos polskiego księgowego w realiach rachunkowości wariantowejartykut dyskusyjny, ,Zeszyty Teoretyczne Rachunkowości” 61, 2011, s. 107-129.

${ }^{39}$ M. Friedman, The Social Responsibility of Business Is to Increase It's Profits, „,New York Times Magazine" z 13 września 1979 r.
} 
ruszeniem norm etycznych. Oznacza to, że prawo, z wyjątkiem prawa zwyczajowego opartego w dużym stopniu na kategorii społecznej zemsty (lex talionis), nie ma bezpośrednich powiązań z etyką. Prawo nie jest tożsame ani też nie symbolizuje kategorii etycznej, jaką jest: ,,sprawiedliwość”. Brak jest też powiązań liberalnego podejścia do prawa z etyką.

Dlatego też państwo winno zwrócić szczególną uwagę na jakość tworzenia prawa, gdyż istnieje społeczna zgoda na wykorzystywanie jego luk. Będąca bez wątpienia - w roku 1994 - dużym postępem w polskim prawodawstwie gospodarczym, ustawa o rachunkowości, z biegiem lat stała się typowym bublem prawnym obrazującym stan poziomu inteligencji i umiejętności przewidywania kolejnych ekip rządzących i posłów zasiadających w polskim parlamencie. Bublem, który prawnie zalegalizował działania $\mathrm{z}$ zakresu inżynierii rachunkowości ${ }^{40}$.

\author{
dr Leszek Michalczyk \\ Uniwersytet Jagielloński $w$ Krakowie
}

\title{
THE LEVEL OF FINANCIAL OUTCOME OF AN ENTERPRISE AND THE POLISH BALANCE SHEET LAW
}

\author{
Summary
}

The aim of this paper is to show how accounting methods set forth in the Polish balance sheet law may affect the financial result of a business entity. The acceptance of variantablity as a model of the balance sheet law has deprived accounting of its methodological objectivity in relation to its subject which is defining the economic achievements of an enterprise. It is the enterprise management that, according to the Accountancy Act, has a right to choose the methods of accounting for the assets and liabilities of a given company or determining its financial outcome. Taking all the above into account, we observe a new phenomenon, namely that those who manage a business may also assess themselves. Such procedures call into question the possibility of using the control procedures by the capital owners. The paper also deals with the influence of particular items of the Polish balance sheet law on the financial outcome of a given enterprise in variant accounting.

${ }^{40}$ Termin za: L. Michalczyk - por. idem, Funkcja informacyjna inżynierii rachunkowości „Pieniądze i Więź” 2011, nr 1 (50), s. 115-132; idem, Inżynieria rachunkowości w ujęciu kauzalnym Ogólnej Teorii Systemów, „Pieniądze i Więź” 2011, nr 2 (51), s. 103-111; idem, Inżynieria rachunkowości $w$ świetle koncepcji earnings managementu jako system informacyjny definiujacy wynik finansowy przedsiębiorstw, w: Z. E. Zieliński (red.), Rola informatyki w naukach ekonomicznych $i$ spotecznych, t. 2 , Wyd. WSH Kielce, Kielce 2010, s. 289-298; idem, Wspótczesne nurty rachunkowości w aspekcie realizacji celów ekonomicznych przedsiębiorstw, „Przegląd Organizacji” 2011, nr 2, s. 34-38; idem, Wykrywanie księgowych działań z zakresu inżynierii rachunkowości, ,,Wrocławski Biuletyn Gospodarczy” (,Problemy zarządzania”), PTE, 2011, nr 42, s. 87-114; idem, Zastosowanie programów informatycznych jako narzędzia wykrywajacego procedury księgowego manipulowania wynikiem finansowym, w: Z. E. Zieliński (red.), op. cit., s. 178-187. 
